\title{
Association between angiotensin II receptor type 1 A1166C polymorphism and chronic kidney disease
}

\author{
Hsien-Feng Chang ${ }^{1}$, Po-Jen Hsiao ${ }^{2,3,4}$, Yu-Juei Hsu ${ }^{2}$, Fu-Huang Lin ${ }^{1}$, Chin Lin ${ }^{1}$, Wen \\ Su $^{5}$, Hsiang-Cheng Chen ${ }^{6, *}$ and Sui-Lung Su${ }^{1, *}$ \\ ${ }^{1}$ School of Public Health, National Defense Medical Center, Taiwan, ROC \\ ${ }^{2}$ Division of Nephrology, Department of Medicine, Tri-Service General Hospital, National Defense Medical Center, Taiwan, ROC \\ ${ }^{3}$ Department of Internal Medicine, Taoyuan Armed Forces General Hospital, Taiwan, ROC \\ ${ }^{4}$ Big Data Research Center, Fu-Jen Catholic University, Taiwan, ROC \\ ${ }^{5}$ Department of Nursing, Tri-Service General Hospital, Taiwan, ROC \\ ${ }^{6}$ Division of Rheumatology/Immunology/Allergy, Department of Internal Medicine, Tri-Service General Hospital, National \\ Defense Medical Center, Taiwan, ROC \\ *These authors have contributed equally to this work \\ Correspondence to: Sui-Lung Su, email: a131419@gmail.com \\ Hsiang-Cheng Chen, email: hccheng@ndmctsgh.edu.tw \\ Keywords: angiotensin II receptor type 1; AGTR 1 A 1 166C; chronic kidney disease; meta-analysis; gene-environment interaction \\ Received: June 08, 2017 Accepted: February 03, 2018 Epub: February 12, 2018 Published: March 06, 2018 \\ Copyright: Chang et al. This is an open-access article distributed under the terms of the Creative Commons Attribution License \\ 3.0 (CC BY 3.0), which permits unrestricted use, distribution, and reproduction in any medium, provided the original author and \\ source are credited.
}

\section{ABSTRACT}

Studies of the association between angiotensin II receptor type 1 A1166C (AGTR1 A1166C) polymorphism and chronic kidney disease (CKD) risk have yielded conflicting results. We conducted a combined case-control study and meta-analysis to better define this association. The case-control study included 634 end-stage renal disease (ESRD) patients and 739 healthy controls. AGTR1 A1166C genotype was determined using polymerase chain reaction and iPLEX Gold SNP genotyping methods. The metaanalysis included 24 studies found in the PubMed and Cochrane Library databases. Together, the case-control study and meta-analysis included 36 populations $(7,918$ cases and 6,905 controls). We found no association between the $C$ allele and ESRD (case-control study: OR: 1.02, 95\% CI: 0.77-1.37; meta-analysis: OR: 1.07; 95\% CI: 0.97-1.18). Co-dominant, dominant, and recessive model results were also not significant. No known environmental factors moderated the effect of AGTR1 A1166C on CKD in our gene-environment interaction analysis. Sensitivity analysis showed an AGTR1 A1166C-CKD association in Indian populations (OR: 1.46, 95\% CI: 1.26-1.69), but not in East Asian or Caucasian populations. Additional South Asian studies will be required to confirm the potential role of this polymorphism in CKD.

\section{INTRODUCTION}

Chronic kidney disease (CKD) is highly prevalent worldwide [1-4], and increases patient cardiovascular event and mortality risks [5]. Genetic factors play key roles in CKD pathogenesis. For example, creatinine clearance appears inherited in $46 \%$ of cases [6]. Identification and evaluation of novel candidate gene polymorphisms could lead to improved CKD diagnostic accuracies and therapeutic options.

The renin-angiotensin system (RAS) regulates blood pressure and electrolyte balance, and an over-active RAS leads to CKD [7]. RAS functions mainly through its final product, angiotensin II (Ang II), which binds 
Ang II receptor types 1 (AGTR1) and 2 (AGTR2) $[8,9]$. Because AGTR2 is highly expressed in fetal tissues, but only weakly expressed in adult tissues $[10,11]$, current CKD genetic research focuses on AGTR1. The silent polymorphism, A1166C (rs5186), is located in the human AGTR1 3'-UTR (untranslated region) [12]. This region is recognized by microRNA-155 (miR-155), and patients harboring the A allele exhibit higher miR-155 and AGTR1 levels than those with the $\mathrm{C}$ allele [13].

Previous studies found associations between AGTR1 A1166C and coronary artery disease [14] and breast cancer [15], although genome-wide association studies (GWASs) [16-18] found no significant AGTR1associated signals. However, GWASs are limited because they tend to explain only a small amount of phenotypic variance, making it difficult to mechanistically assign the loss of function of a specific gene to a single polymorphism $[19,20]$. These might be attributable to missing heritability, which is hidden in gene-environment interactions [21, 22]. Additionally, the amount of variance attributable to a SNP detected in a GWAS is likely to be less than that attributable to a true causal variant [23]. Although many previous meta-analyses have investigated AGTR1 A1166C polymorphisms in CKD, their sample sizes were small. Additionally, to our knowledge, no studies have considered gene-environment interactions $[12,24]$. We performed a case-control study to investigate the association between AGTR1 A1166C and CKD, and a subsequent meta-analysis combining our data with current evidence. Our systematic analysis provides a clearer understanding of the effect of AGTR1 A1166C on CKD.

\section{RESULTS}

\section{Case-control study}

Case and control patient characteristics are shown in Table 1. We included 634 cases with a mean age of $64.5 \pm 14.9$ years (296 men and 338 women) and 739 controls with a mean age of $72.7 \pm 7.2$ years (298 men and 441 women). Mean age was higher among controls relative to cases $(\mathrm{p}=0.001)$, and sex distribution differed between the groups $(\mathrm{p}=0.015)$. The control group had a higher average BMI than the case group $(\mathrm{p}=0.001)$.

A control sample cannot be genotyped, so the genotyping call rate in this study is $99.9 \%$. Now there are only 634 cases and 738 controls in further analysis. We used four types of genetic models to test the association between AGTR1 A1166C and ESRD; the result is shown in Table 2. AGTR1 A1166C C allele frequencies were $6.4 \%$ and $6.2 \%$ in cases and controls, respectively. The $\mathrm{C}$ allele-CKD association was nonsignificant (OR: 1.02; 95\% CI: 0.77-1.37). Results from the co-dominant, dominant, and recessive models were also nonsignificant. We further analyzed the association between AGTR1 A1166C and ESRD after adjusting age, sex, BMI, hypertension, DM, and smoking, because these factors differed between controls and cases. However, multivariate analysis results were nonsignificant.

\section{Meta-analysis}

The study identification process is shown in Figure 1. For AGTR1 A1166C and CKD, our search returned 77 records from PubMed, the Cochrane Library, and manual scans. We excluded 25 papers after a preliminary review of the titles and abstracts. An additional 18 papers were excluded after assessing the full-text articles, leaving 34 articles that matched our criteria. Of these, seven used duplicate databases and four lacked detailed data. Of the 23 studies that were ultimately included [25-47], Thomas, et al. [42], Kim, et al. [33], Mollsten, et al. [31], and Shah, et al. [29] reported results in the context of stratification. Our meta-analysis of AGTR1 A1166C and CKD therefore comprised 35 populations, including our case-control study (Supplementary Table 3).

An AGTR1 A1166C and CKD forest plot was calculated using the allele model (Figure 2). The overall pooled result showed no significant association between AGTR1 A1166C and CKD (OR: 1.07; 95\% CI: $0.97-$ 1.18 ), and a subgroup analysis found no significant results in Caucasian populations (OR: 1.03; 95\% CI: 0.91-1.18). However, the $\mathrm{C}$ allele is a CKD risk factor in Asian populations (OR: 1.18; 95\% CI: 1.01-1.38). These results demonstrate heterogeneity and indicate the need for further analysis. Dominant and recessive model results were similar to those of the allele model (Table 3). Careful examination identified three studies [27, 29, 34] that were not suitable for inclusion in the Asian subgroup. Gao, et al. [27] reported a $93.9 \%$ minor allele frequency in a Chinese population, which differed greatly from other Chinese studies and the 1,000 Genomes Database [48]. Additionally, Asian populations can be subdivided into East and South Asians, whose allele frequencies may differ [48]. Thus, we included two studies [29, 34] from India within an independent subgroup. Result were not significant in the East Asian subgroup (OR: 1.00; 95\% CI: 0.82-1.23), but were in the Indian subgroup (OR: 1.45; 95\% CI: 1.23-1.73) (Figure 3). After further stratification, heterogeneities in these two subgroup disappeared. Dominant and recessive model results were similar to those of the allele model (Table 4).

We used meta-regression to detect potential geneenvironment interactions that could explain the high heterogeneity among these studies (Table 5). None of the investigative factors moderated the effect of AGTR1 A1166C on CKD. We also excluded the three studies deemed unsuitable for inclusion in the Asian subgroup $[27,29,34]$ to avoiding confounding effects. Table 6 shows the meta-regression sensitivity analysis results. DM prevalence is the only significant moderator after Bonferroni correction (OR: 0.58; 95\% CI: $0.43-0.78$; 
Table 1: ESRD and control subject characteristics

\begin{tabular}{lccc}
\hline & Case (N=634) & Control (N=739) & p-value \\
\hline Age (years) & $64.5 \pm 14.9$ & $72.7 \pm 7.2$ & $<0.001$ \\
Sex (\% male) & $296(46.7 \%)$ & $298(40.2 \%)$ & 0.015 \\
BMI (kg/m $\left.{ }^{2}\right)$ & $22.4 \pm 4.0$ & $24.1 \pm 3.2$ & $<0.001$ \\
Hypertension & $332(57.8 \%)$ & $303(40.8 \%)$ & $<0.001$ \\
DM & $213(54.2 \%)$ & $91(12.3 \%)$ & $<0.001$ \\
TC (mg/dL) & $166.0 \pm 36.1$ & $191.0 \pm 32.5$ & $<0.001$ \\
TG (mg/dL) & $158.5 \pm 109.7$ & $116.1 \pm 60.2$ & $<0.001$ \\
Creatinine (mg/dL) & $9.6 \pm 2.5$ & $0.8 \pm 0.2$ & $<0.001$ \\
eGFR (ml/min/1.73m $\left.{ }^{2}\right)$ & $5.5 \pm 1.9$ & $90.5 \pm 15.7$ & $<0.001$ \\
Smoke & $122(21.1 \%)$ & $76(10.3 \%)$ & $<0.001$ \\
\hline
\end{tabular}

Abbreviations: BMI: body-mass index; DM: diabetes mellitus; TC: total cholesterol; TG: triglycerides; eGFR: estimated glomerular filtration rate.

Table 2: AGR1 A1166C genotype frequencies in cases and controls

\begin{tabular}{|c|c|c|c|c|c|c|}
\hline & Case & Control & Crude-OR (95\% CI) & p-value & Adj-OR (95\% CI) & p-value \\
\hline \multicolumn{7}{|l|}{ Allele } \\
\hline $\mathbf{A}$ & $1187(93.6 \%)$ & $1384(93.8 \%)$ & 1 & 0.876 & 1 & 0.998 \\
\hline C & $81(6.4 \%)$ & $92(6.2 \%)$ & $1.02(0.77-1.37)$ & & $1.00(0.62-1.60)$ & \\
\hline \multicolumn{7}{|c|}{ Co-dominant } \\
\hline $\mathbf{A A}$ & $560(88.3 \%)$ & $656(88.9 \%)$ & 1 & 0.816 & 1 & 0.429 \\
\hline $\mathrm{AC}$ & $67(10.6 \%)$ & $72(9.8 \%)$ & $1.09(0.77-1.55)$ & & $1.25(0.70-2.22)$ & \\
\hline $\mathrm{CC}$ & $7(1.1 \%)$ & $10(1.4 \%)$ & $0.82(0.31-2.17)$ & & $0.43(0.09-2.17)$ & \\
\hline \multicolumn{7}{|c|}{ Dominant } \\
\hline $\mathbf{A A}$ & $560(88.3 \%)$ & $656(88.9 \%)$ & 1 & 0.676 & 1.00 & 0.293 \\
\hline $\mathrm{AC}+\mathrm{CC}$ & $74(11.7 \%)$ & $82(11.1 \%)$ & $0.81(0.31-2.15)$ & & $0.42(0.08-2.11)$ & \\
\hline \multicolumn{7}{|c|}{ Recessive } \\
\hline $\mathbf{A A}+\mathbf{A C}$ & $627(98.9 \%)$ & $728(98.6 \%)$ & 1 & 0.744 & 1.00 & 0.703 \\
\hline $\mathbf{C C}$ & $7(1.1 \%)$ & $10(1.4 \%)$ & $1.06(0.76-1.48)$ & & $1.11(0.64-1.93)$ & \\
\hline
\end{tabular}

OR: odds ratio; CI: confidence interval; Adj-OR: odds ratio after adjusting for age, sex, BMI, hypertension, DM, and smoking habits.

$\mathrm{p}<0.001$ ), but Egger's regression analysis shows asymmetry in this result ( $\mathrm{p}=0.008)$. Because a previous study considered asymmetry to imply some bias [49], we concluded that our meta-regression results were not robust. In summary, no investigative factors moderated the effects of AGTR1 A1166C on CKD.

\section{DISCUSSION}

Both our case-control study and meta-analysis revealed no association between AGTR1 A1166C and ESRD. Subgroup analyses identified an association between AGTR1 A1166C and CKD among Asian 
populations, but this was not significant in East Asians. Although patients with the AGTR1 A1166C A allele exhibit higher miR-155 and AGTR1 levels than those with the C allele [13], and this polymorphism is associated with coronary artery disease [14] and breast cancer [15], current evidence does not support an association between AGTR1 A1166C and CKD in East Asians.

The AGTR1 A1166C-CKD association in the Asian patient subgroup might be attributable to the Indian population, based on sensitivity analysis. Although previous meta-analyses included Indian studies within the Asian subgroup [12, 24], the 1,000 Genomes Project separated South and East Asians into different racial categories [48]. Heterogeneity in our study disappeared after this same classification. Additionally, the association between RAS polymorphism and CKD is complex, and includes gene-gene [50] and gene-environment
[51] interactions. Thus, a small racial difference might increase heterogeneity. Moreover, the observed high level of heterogeneity in Caucasians implies that some factor may moderate the effects of AGTR1 A1166C on CKD, but our attempts to explain this heterogeneity using all known factors did not yield significant findings. Future research should focus on the effects of gene-gene interactions on CKD, and additional studies conducted in South Asia will better illustrate the role of AGTR1 A1166C in CKD.

This study had several limitations. First, we relied on tabular data for the meta-analysis, rather than individual patient data. However, a previous study revealed that the inclusion of summary data could increase the sample size and improve confidence [52]. Additionally, our case-control study and meta-analysis yielded similar results. Second, gene-environment interaction analyses are limited by the availability of published data. For
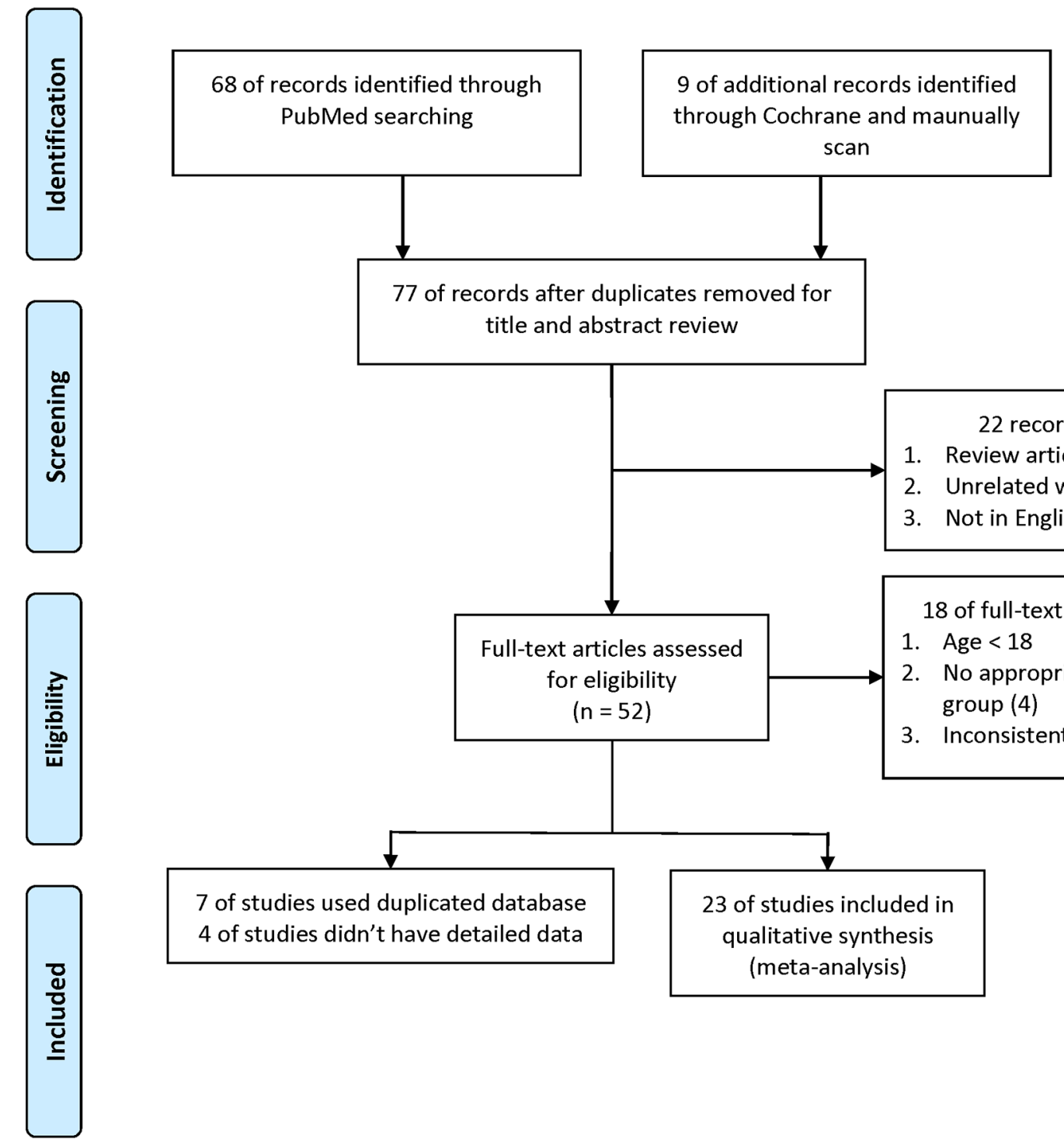

9 of additional records identified

through Cochrane and maunually

scan

22 records excluded:

1. Review article (6)

2. Unrelated with this study (16)

3. Not in English (3)

18 of full-text articles excluded:

1. Age $<18$

2. No appropriate controlled group (4)

3. Inconsistent CKD deinition (4)

Figure 1: Meta-analysis study identification process. 
example, the included studies each only reported a few factors. Third, gene-gene interactions are difficult to analyze in the context of a meta-analysis. Although our previously-developed method addresses this problem [53], published papers seldom simultaneously report the same polymorphisms. We will conduct a multi-loci metaanalysis in the event that sufficient papers are published.
In conclusion, our meta-analysis found that the AGTR1 A1166C-CKD association was only significant in the Indian subgroup, and more South Asian studies are needed to confirm this finding. The AGTR1 A1166C C allele is likely not a CKD risk factor in East Asians and Caucasians. The observed high level of heterogeneity among studies suggests a complex

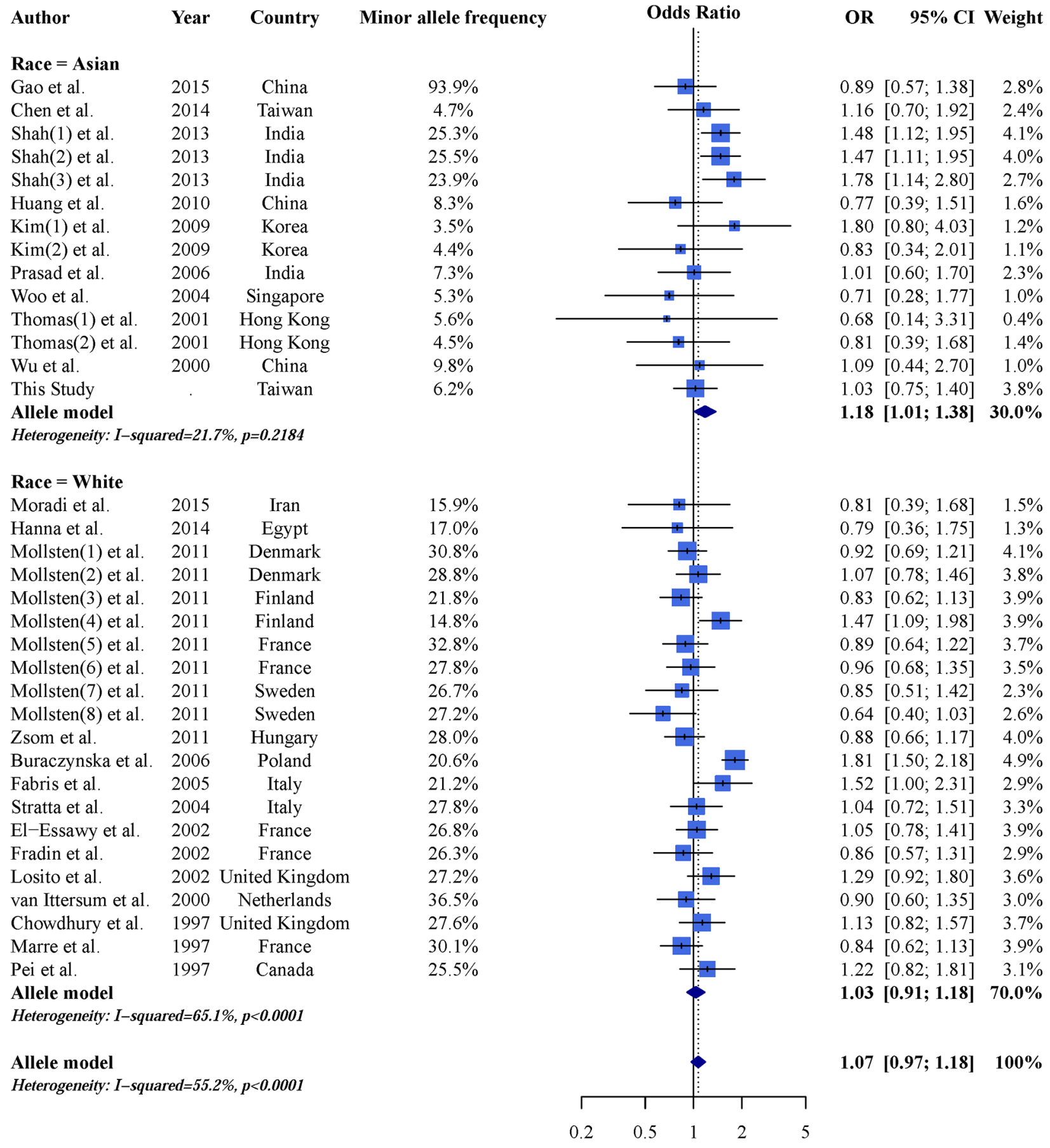

Figure 2: Allele model AGTR1 A1166C and CKD forest plot. 
Table 3: AGTR1 A1166C and CKD odds ratios using allele, dominant, and recessive model assumptions

\begin{tabular}{|c|c|c|c|c|c|c|c|c|c|c|c|c|}
\hline \multirow[t]{2}{*}{ Model } & \multicolumn{4}{|c|}{ Total } & \multicolumn{4}{|c|}{ Asian } & \multicolumn{4}{|c|}{ White } \\
\hline & OR & $95 \%$ CI & $\mathbf{I}^{2}$ & $\begin{array}{l}\text { Egger's } \\
\text { test }\end{array}$ & OR & $95 \% \mathrm{CI}$ & $\mathbf{I}^{2}$ & $\begin{array}{l}\text { Egger's } \\
\text { test }\end{array}$ & OR & $95 \%$ CI & $\mathbf{I}^{2}$ & $\begin{array}{c}\text { Egger's } \\
\text { test }\end{array}$ \\
\hline \multicolumn{13}{|l|}{ Overall analysis } \\
\hline Allele (C vs. A) & 1.07 & $\begin{array}{c}0.97- \\
1.18\end{array}$ & $55.2 \%$ & 0.367 & 1.18 & $1.01-1.38$ & $21.7 \%$ & 0.205 & 1.03 & $0.91-1.18$ & $65.1 \%$ & 0.033 \\
\hline $\begin{array}{l}\text { Dominant }(\mathrm{CC}+ \\
\mathrm{AC} \text { vs AA) }\end{array}$ & 1.06 & $\begin{array}{c}0.94- \\
1.20\end{array}$ & $51.3 \%$ & 0.040 & 1.17 & $1.00-1.36$ & $0.0 \%$ & 0.060 & 1.02 & $0.87-1.20$ & $64.8 \%$ & 0.024 \\
\hline $\begin{array}{l}\text { Recessive (CC vs } \\
\mathrm{AA}+\mathrm{AC})\end{array}$ & 1.26 & $\begin{array}{l}0.96- \\
1.65\end{array}$ & $60.0 \%$ & 0.118 & 2.31 & $0.96-5.54$ & $77.7 \%$ & 0.095 & 1.10 & $0.84-1.44$ & $49.2 \%$ & 0.657 \\
\hline
\end{tabular}

Abbreviations: I²: index of study heterogeneity; Egger's test: p-value of Egger's regression for asymmetry assessment.

underlying mechanism that appears unrelated to patient sex, age, BMI, DM, hypertension, or smoking habits. Because this unexplainable heterogeneity might be related to gene-gene interactions, an AGTR1 A1166CCKD epistasis analysis should be conducted. Some RAS
I/D and angiotensinogen M235T, may moderate the association between AGTR1 A1166C and CKD. Finally, potential gene-environment interactions may influence this association, and additional environmental factors should be investigated.

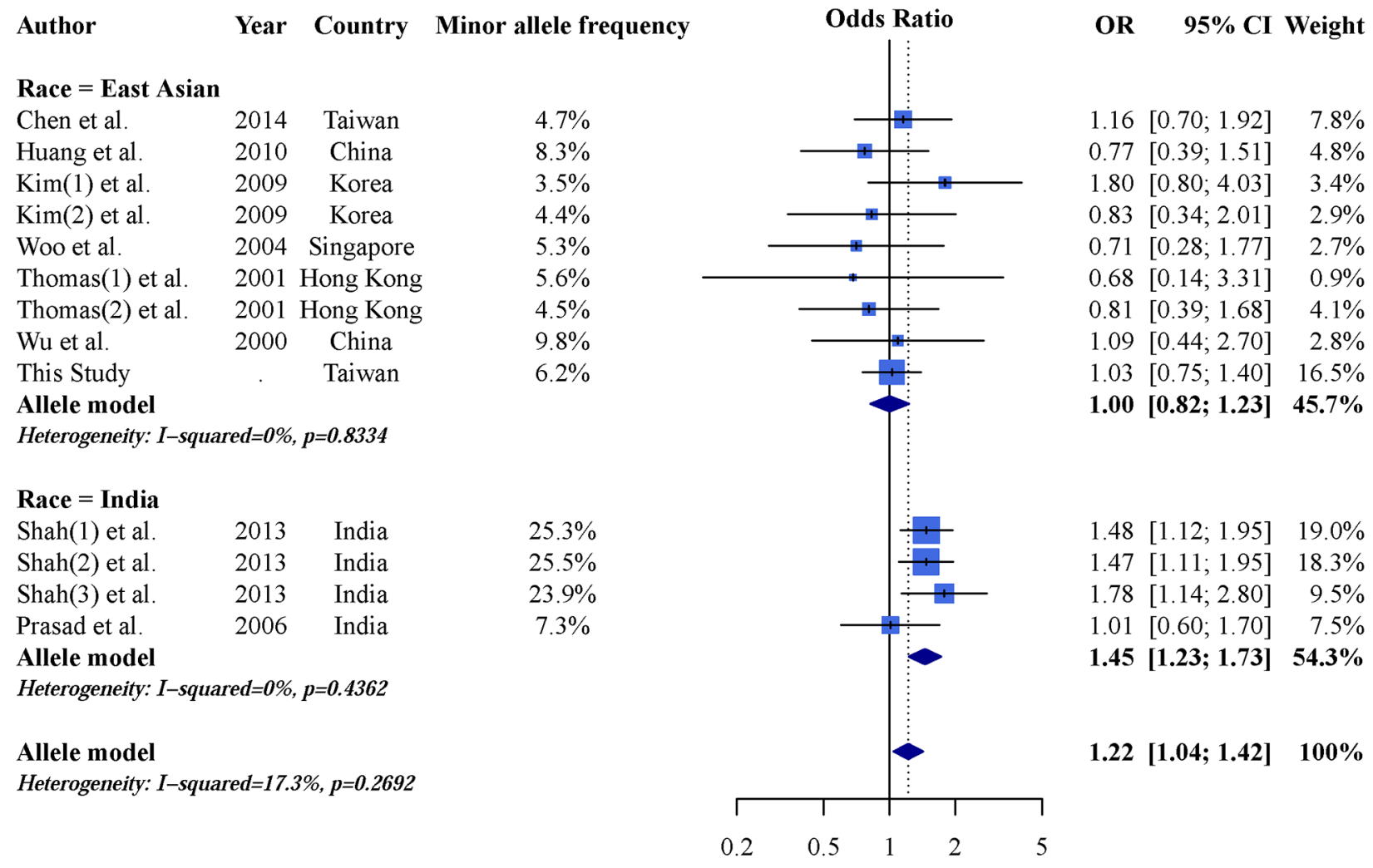

Figure 3: Allele model forest plot of AGTR1 A1166C and CKD in east Asian and Indian populations.

polymorphisms, such as angiotensin converting enzyme 
Table 4: AGTR1 A1166C and CKD odds ratios in east Asian and Indian populations using allele, dominant, and recessive model assumptions

\begin{tabular}{|c|c|c|c|c|c|c|c|c|}
\hline \multirow[t]{2}{*}{ Model } & \multicolumn{4}{|c|}{ East Asian $^{a}$} & \multicolumn{4}{|c|}{ Indian } \\
\hline & OR & $95 \% \mathrm{CI}$ & $\mathbf{I}^{2}$ & Egger's test & OR & $95 \% \mathrm{CI}$ & $\mathbf{I}^{2}$ & Egger's test \\
\hline \multicolumn{9}{|l|}{ Sensitivity analysis } \\
\hline Allele (C vs. A) & 1.00 & $0.82 ; 1.23$ & $0 \%$ & 0.504 & 1.45 & $1.23-1.73$ & $0 \%$ & 0.603 \\
\hline Dominant $(\mathrm{CC}+\mathrm{AC}$ vs $\mathrm{AA})$ & 1.01 & $0.81 ; 1.25$ & $0 \%$ & 0.387 & 1.36 & $1.09-1.68$ & $0 \%$ & 0.792 \\
\hline Recessive (CC vs AA + AC) & 0.81 & $0.31 ; 2.15$ & $0 \%$ & $\mathrm{NA}^{\mathrm{b}}$ & 4.95 & $2.66-9.20$ & $0 \%$ & 0.239 \\
\hline
\end{tabular}

a: Sensitivity analysis excluded three studies as described in Results.

b: Analysis included only one population.

Table 5: Moderator effects of the allele model (C vs. A) on AGTR1 A1166C and CKD

\begin{tabular}{lccccccc}
\hline & $\mathbf{n}$ & $\boldsymbol{\tau}^{\mathbf{2}}$ & Adjust $\boldsymbol{\tau}^{2}$ & OR & $\mathbf{9 5 \%}$ CI & p-value & Egger's test p-value $^{\mathbf{9}}$ \\
\hline Race & 35 & 0.0452 & 0.0460 & 0.90 & $0.72-1.12$ & 0.345 & 0.011 \\
Study design & 35 & 0.0452 & 0.0423 & 1.09 & $0.90-1.34$ & 0.382 & 0.039 \\
Quality score (per 1 score) & 35 & 0.0452 & 0.0425 & 1.08 & $0.97-1.19$ & 0.152 & 0.063 \\
Kidney function of case & 35 & 0.0452 & 0.0341 & 1.21 & $0.95-1.54$ & 0.129 & 0.108 \\
Gender (per 100\%) & 33 & 0.0480 & 0.0502 & 1.00 & $0.70-1.42$ & 0.977 & 0.087 \\
Age (per 10 year) & 34 & 0.0473 & 0.0436 & 1.09 & $0.98-1.20$ & 0.104 & 0.093 \\
BMI (per 5 kg/m²) & 11 & 0.0393 & 0.0488 & 0.95 & $0.65-1.38$ & 0.790 & 0.263 \\
Hypertension (per 100\%) & 29 & 0.0552 & 0.0487 & 1.63 & $0.80-3.32$ & 0.178 & 0.064 \\
DM (per 100\%) & 25 & 0.0603 & 0.0352 & 0.69 & $0.48-1.00$ & 0.051 & 0.017 \\
Smoke (per 100\%) & 11 & 0.0102 & 0.0123 & 1.58 & $0.34-7.41$ & 0.562 & 0.355 \\
\hline
\end{tabular}

Dependent variable: log odds ratio of AGTR1 A1166C and CKD using allele model.

Abbreviations: n: number of studies; OR: odds ratio for moderator effects; CI: confidence interval.

Race: Asian is reference; study design: cross-sectional study is reference; kidney function of case: not only ESRD patients as reference; gender: proportion of males; age: mean age; BMI: body mass index; hypertension: hypertension prevalence; DM: diabetes mellitus prevalence; Smoke: smoking prevalence.

s: $\mathrm{P}<0.05 / 10$ is considered significant due to Bonferroni correction.

Table 6: Meta-regression sensitivity analysis

\begin{tabular}{|c|c|c|c|c|c|c|c|}
\hline & $\mathbf{n}$ & $\tau^{2}$ & Adjust $\tau^{2}$ & OR & $95 \% \mathrm{CI}$ & p-value $\$$ & Egger's test p-value \\
\hline Race & 30 & 0.0429 & 0.0448 & 1.05 & $0.78-1.41$ & 0.747 & 0.090 \\
\hline Study design & 30 & 0.0429 & 0.0264 & 1.24 & $1.02-1.50$ & 0.031 & 0.027 \\
\hline Quality score (per 1 score) & 30 & 0.0429 & 0.0462 & 1.01 & $0.89-1.16$ & 0.848 & 0.109 \\
\hline Kidney function of case & 30 & 0.0429 & 0.0205 & 1.30 & $1.05-1.62$ & 0.017 & 0.198 \\
\hline Gender (per 100\%) & 28 & 0.0462 & 0.0490 & 1.00 & $0.70-1.43$ & 0.999 & 0.142 \\
\hline Age (per 10 years) & 29 & 0.0452 & 0.0470 & 1.04 & $0.93-1.17$ & 0.458 & 0.134 \\
\hline BMI (per $5 \mathrm{~kg} / \mathrm{m}^{2}$ ) & 8 & 0.0110 & 0.0210 & 0.93 & $0.67-1.30$ & 0.687 & 0.520 \\
\hline Hypertension (per 100\%) & 25 & 0.0545 & 0.0366 & 1.96 & $0.98-3.92$ & 0.057 & 0.117 \\
\hline $\mathrm{DM}($ per $100 \%)$ & 20 & 0.0736 & 0.0121 & 0.58 & $0.43-0.78$ & $<0.001$ & 0.008 \\
\hline Smoke (per $100 \%$ ) & 11 & 0.0102 & 0.0123 & 1.58 & $0.34-7.41$ & 0.562 & 0.355 \\
\hline
\end{tabular}

Dependent variable: log odds ratio of AGTR1 A1166C and CKD using allele model.

Abbreviations: n: number of studies; OR: odds ratio for moderator effects; CI: confidence interval.

Race: Asian is reference; study design: cross-sectional study is reference; kidney function of case: not only ESRD patients as reference; gender: proportion of males; age: mean age; BMI: body mass index; hypertension: hypertension prevalence;

DM: diabetes mellitus prevalence; smoke: smoking prevalence.

s: $\mathrm{P}<0.05 / 10$ is considered significant due to Bonferroni correction. 


\section{MATERIALS AND METHODS}

\section{Case-control study population size}

Based on the following thresholds, the minimum required study sample size was 1047 subjects: twosided test with a power $(1-\beta)=0.8$ at a significance level of 0.05 , ratio of controls to cases $=1$, hypothetical proportion of controls with exposure $=9$, and least extreme odds ratio (OR) to be detected $=1.5$ [54]. We initiated a population-based study at Tri-Service General Hospital (TSGH), a medical teaching hospital of the National Defense Medical Center in Taipei, Taiwan. This study was reviewed and approved by the Tri-Service General Hospital institutional ethical committee (TSGH1-104-05-006). All enrolled study participants provided signed informed consent.

\section{Subjects}

The case group was recruited from TSGH dialysis centers. All included patients were undergoing dialysis treatment and had been diagnosed with end-stage renal disease (ESRD). We recruited controls at the TSGH Health Management Center from patients participating in a checkup program beginning in March 2011. Control inclusion criteria were as follows: (1) estimated glomerular filtration rate (eGFR) of $>60 \mathrm{ml} / \mathrm{min} / 1.73 \mathrm{~m}^{2}$ as calculated using the MDRD equation; (2) no symptoms of kidney damage (e.g. proteinuria, hematuria); (3) no serious diseases (e.g. cancer), (4) able to provide a sufficient blood sample for genotyping. Patient demographic data, including age, sex, body mass index (BMI: $\mathrm{kg} / \mathrm{m}^{2}$ ), history of hypertension, history of diabetes mellitus (DM), and smoking habits, were collected from medical records. Biochemistry laboratory values, such as total cholesterol, triglyceride, and creatinine levels, were collected from electronic health records. In total, 634 cases (296 men and 338 women) and 739 controls (298 men and 441 women) participated in this study up to July 2015 .

\section{Genomic DNA extraction and genotyping}

Genomic DNA was extracted from peripheral blood samples using standard proteinase $\mathrm{K}$ (Invitrogen, Carlsbad, CA, USA) digestion and phenol/chloroform extraction methods. AGTR1 A1166C polymorphisms were genotyped using the iPLEX Gold SNP genotyping method [55]. To validate results, at least $10 \%$ of samples were randomly selected for repeated genotyping.

\section{Case-control study statistical analysis}

Continuous variables were evaluated using Student's $t$ test and reported as means \pm standard deviations (SDs). Genotypes and allelic frequencies were compared between dialysis patients and healthy controls using the $\chi^{2}$ test or Fisher's exact test as appropriate. Logistic regression was used to estimate ORs and 95\% confidence intervals (CIs) as measures of the association with CKD risk. Allele type, co-dominant, and dominant/recessive models were used to calculate the association between genetic polymorphism and $\mathrm{CKD}$ risk. $\mathrm{P}<0.05$ was considered significant. Statistical analyses were conducted using $\mathrm{R}$ software, version 3.3.1 (R Project for Statistical Computing, Vienna, Austria).

\section{Meta-analysis search methods and criteria for study consideration}

The PRISMA checklist and Meta-analysis of Genetic Association Studies Checklist are described in Supplementary Table 1 [56]. This general population study compared CKD risk between individuals carrying the major (A) or minor (C) AGTR1 A1166C alleles. To identify relevant studies, we searched the PubMed and Cochrane Library databases for English-language articles using relevant words and medical subject headings that included all spellings of AGTR1 A1166C and CKD (Supplementary Table 2). We also manually scanned reference lists of identified trials and review articles to avoid missing relevant studies. We included all articles published from the dates of inception of these databases to December 2015.

All studies that assessed the association between AGTR1 A1166C and CKD risk were considered for inclusion using the following criteria: (1) cross-sectional surveys or case-control studies; (2) study population aged >18 years; (3) CKD defined according to the National Kidney Foundation as kidney damage by clinical diagnosis or a glomerular filtration rate $<60 \mathrm{ml} / \mathrm{min} / 1.73$ $\mathrm{m} 2$; (4) inclusion of at least one control group with normal kidney function; and (5) detailed genotype information. Common genetic association study methods included co-dominant, allele, dominant, and recessive models, although some papers only presented significant results. We only included papers with detailed information about genotypes. Studies that investigated relationships between genetic polymorphisms and other kidney diseases (lupus nephritis, polycystic kidney disease, endemic nephropathy, or reflux nephropathy) were excluded. For manuscripts with incomplete published data, we attempted to contact the authors for further information.

\section{Data extraction and quality assessment}

We recorded the first author's name, publication year, study population ethnicity, kidney functions of cases, definition of the case group, and case group population characteristics (mean age, proportion of male subjects, BMI, DM prevalence, hypertension prevalence, proportion of smokers, and AGTR1 A1166C genotype distribution). 
$\mathrm{DM}$ and hypertension were defined as plasma glucose $>126 \mathrm{mg} / \mathrm{dL}$ and systolic blood pressure $>140 \mathrm{mmHg}$, respectively. If the article did not report DM and hypertension prevalence, or the definitions did not match, we assumed normal plasma glucose level and systolic blood pressure distributions for calculation purposes.

Bias risk was assessed via the Cochrane Collaboration, as suggested by the Newcastle-Ottawa Quality Assessment Scale [57]. This tool focuses on the following factors: (1) selection of study population, (2) case and control group comparability, and (3) assessed exposure. Each study received a score between 0 and 9 . We investigated the relationship between study quality and risk estimation.

\section{Meta-analysis statistical analysis}

Population characteristics of each included study are presented as means or proportions as appropriate. Our metaanalysis examined the association between AGTR1 A1166C and CKD risk in each study using ORs with $95 \%$ CIs. The $\tau^{2}$ statistic, estimated according to the DerSimonian-Laird method, was used to assess heterogeneity, and a randomeffects model was used to calculate weighed effect size. Three common genetic models (allele type, dominant, and recessive models) were used to calculate the association between AGTR1 A1166C and CKD risk.

Egger's regression and a funnel plot were used to test the symmetry of pooled results. The $\mathrm{I}^{2}$ value was calculated using the Cochrane $\mathrm{Q}$ test and used to quantify heterogeneity; an $\mathrm{I}^{2}$ value $>50 \%$ indicated moderate to high heterogeneity. A meta-regression analysis of average summary values was used to explore the source of heterogeneity. According to our previous studies, the average summary value of a case group can be used to build a model and can facilitate interaction effect estimation [58]. An interaction effect is determined using the OR and defined as the ratio of ORs per unit. Possible moderators (race, study design, quality score, kidney function of case, sex, age, BMI, hypertension, DM, and smoking) were tested to explore heterogeneity.

$\mathrm{P}<0.05$ was considered significant. However, because of multiple comparison correction, $\mathrm{P}<0.05 / 10$ was considered significant for meta-regression analyses. Statistical analyses were conducted using the "metafor" and "meta" $\mathrm{R}$ version 3.3.1 packages.

\section{CONFLICTS OF INTEREST}

The authors declare that they have no conflicts of interest.

\section{REFERENCES}

1. Coresh J, Selvin E, Stevens LA, Manzi J, Kusek JW, Eggers P, Van Lente F, Levey AS. Prevalence of chronic kidney disease in the United States. JAMA. 2007; 298:2038-47. https://doi.org/10.1001/jama.298.17.2038.

2. Kuo HW, Tsai SS, Tiao MM, Yang CY. Epidemiological features of CKD in Taiwan. Am J Kidney Dis. 2007; 49:4655. https://doi.org/10.1053/j.ajkd.2006.10.007.

3. Imai E, Horio M, Watanabe T, Iseki K, Yamagata K, Hara S, Ura N, Kiyohara Y, Moriyama T, Ando Y, Fujimoto S, Konta T, Yokoyama H, et al. Prevalence of chronic kidney disease in the Japanese general population. Clin Exp Nephrol. 2009; 13:621-30. https://doi.org/10.1007/ s10157-009-0199-x.

4. Zhang L, Wang F, Wang L, Wang W, Liu B, Liu J, Chen M, He Q, Liao Y, Yu X, Chen N, Zhang JE, Hu Z, et al. Prevalence of chronic kidney disease in China: a crosssectional survey. Lancet. 2012; 379:815-22. https://doi. org/10.1016/S0140-6736(12)60033-6.

5. Go AS, Chertow GM, Fan D, McCulloch CE, Hsu CY. Chronic kidney disease and the risks of death, cardiovascular events, and hospitalization. N Engl J Med. 2004; 351:1296-305. https://doi.org/10.1056/ NEJMoa041031.

6. Fox CS, Yang Q, Cupples LA, Guo CY, Larson MG, Leip EP, Wilson PW, Levy D. Genomewide linkage analysis to serum creatinine, GFR, and creatinine clearance in a community-based population: the Framingham Heart Study. J Am Soc Nephrol. 2004; 15:2457-61. https://doi. org/10.1097/01.ASN.0000135972.13396.6F.

7. Remuzzi G, Perico N, Macia M, Ruggenenti P. The role of renin-angiotensin-aldosterone system in the progression of chronic kidney disease. Kidney Int Suppl. 2005; 68:S57-65. https://doi.org/10.1111/j.1523-1755.2005.09911.x.

8. Harrison-Bernard LM. The renal renin-angiotensin system. Adv Physiol Educ. 2009; 33:270-74. https://doi. org/10.1152/advan.00049.2009.

9. Mehta PK, Griendling KK. Angiotensin II cell signaling: physiological and pathological effects in the cardiovascular system. Am J Physiol Cell Physiol. 2007; 292:C82-97. https://doi.org/10.1152/ajpcell.00287.2006.

10. Lemarié CA, Schiffrin EL. The angiotensin II type 2 receptor in cardiovascular disease. J Renin Angiotensin Aldosterone Syst. 2010; 11:19-31. https://doi. org/10.1177/1470320309347785.

11. Clauser E, Curnow KM, Davies E, Conchon S, Teutsch B, Vianello B, Monnot C, Corvol P. Angiotensin II receptors: protein and gene structures, expression and potential pathological involvements. Eur J Endocrinol. 1996; 134:403-11. https://doi.org/10.1530/eje.0.1340403.

12. Braliou GG, Grigoriadou AM, Kontou PI, Bagos PG. The role of genetic polymorphisms of the Renin-Angiotensin System in renal diseases: A meta-analysis. Comput Struct Biotechnol J. 2014; 10:1-7. https://doi.org/10.1016/j. csbj.2014.05.006.

13. Ceolotto G, Papparella I, Bortoluzzi A, Strapazzon G, Ragazzo F, Bratti P, Fabricio AS, Squarcina E, Gion M, 
Palatini P, Semplicini A. Interplay between miR-155, AT1R A1166C polymorphism, and AT1R expression in young untreated hypertensives. Am J Hypertens. 2011; 24:241-46. https://doi.org/10.1038/ajh.2010.211.

14. Li Y, Li X, Jia N, Guo S, Chu S, Niu W. Meta-analysis of the association between angiotensin II receptor, type 1 gene A1166C polymorphism and coronary artery disease in Chinese populations. J Renin Angiotensin Aldosterone Syst. 2013; 14:82-90. https://doi. org/10.1177/1470320312450599.

15. Xi B, Zeng T, Liu L, Liang Y, Liu W, Hu Y, Li J. Association between polymorphisms of the renin-angiotensin system genes and breast cancer risk: a meta-analysis. Breast Cancer Res Treat. 2011; 130:561-68. https://doi.org/10.1007/ s10549-011-1602-3.

16. Okada Y, Sim X, Go MJ, Wu JY, Gu D, Takeuchi F, Takahashi A, Maeda S, Tsunoda T, Chen P, Lim SC, Wong TY, Liu J, et al, and KidneyGen Consortium, and CKDGen Consortium, and GUGC consortium. Meta-analysis identifies multiple loci associated with kidney functionrelated traits in east Asian populations. Nat Genet. 2012; 44:904-09. https://doi.org/10.1038/ng.2352.

17. Pattaro C, Köttgen A, Teumer A, Garnaas M, Böger CA, Fuchsberger C, Olden M, Chen MH, Tin A, Taliun D, Li M, Gao X, Gorski M, et al, and CARDIoGRAM Consortium, and ICBP Consortium, and CARe Consortium, and Wellcome Trust Case Control Consortium 2 (WTCCC2). Genome-wide association and functional follow-up reveals new loci for kidney function. PLoS Genet. 2012; 8:e1002584. https://doi.org/10.1371/journal. pgen. 1002584.

18. Köttgen A, Glazer NL, Dehghan A, Hwang SJ, Katz R, Li M, Yang Q, Gudnason V, Launer LJ, Harris TB, Smith AV, Arking DE, Astor BC, et al. Multiple loci associated with indices of renal function and chronic kidney disease. Nat Genet. 2009; 41:712-17. https://doi.org/10.1038/ng.377.

19. Hildebrandt F. Genetic kidney diseases. Lancet. 2010; 375:1287-95. https://doi.org/10.1016/ S0140-6736(10)60236-X.

20. Altshuler D, Daly MJ, Lander ES. Genetic mapping in human disease. Science. 2008; 322:881-88. https://doi. org/10.1126/science. 1156409.

21. Manolio TA, Collins FS, Cox NJ, Goldstein DB, Hindorff LA, Hunter DJ, McCarthy MI, Ramos EM, Cardon LR, Chakravarti A, Cho JH, Guttmacher AE, Kong A, et al. Finding the missing heritability of complex diseases. Nature. 2009; 461:747-53. https://doi.org/10.1038/ nature08494.

22. Hunter DJ. Gene-environment interactions in human diseases. Nat Rev Genet. 2005; 6:287-98. https://doi. org/10.1038/nrg1578.

23. Wei WH, Hemani G, Haley CS. Detecting epistasis in human complex traits. Nat Rev Genet. 2014; 15:722-33. https://doi.org/10.1038/nrg3747.
24. Xu JM, Song X, Gao F, Wang R. Association between the AGTR1 A1166C polymorphism and risk of IgA nephropathy: a meta-analysis. Genet Mol Res. 2015; 14:19371-81. https:// doi.org/10.4238/2015.December.29.47.

25. Moradi M, Rahimi Z, Amiri S, Rahimi Z, Vessal M, Nasri H. AT1R A1166C variants in patients with type 2 diabetes mellitus and diabetic nephropathy. J Nephropathol. 2015; 4:69-76.

26. Hanna MO, Shahin RM, Meshaal SS, Kostandi IF. Susceptibility and progression of end stage renal disease are not associated with angiotensin II type 1 receptor gene polymorphism. J Recept Signal Transduct Res. 2015; 35:381-85. https://doi.org/10.3109/10799893.2014.956757.

27. Gao J, Yu QL, Fu RG, Wei LT, Wang M, Dong FM, Wang Z, Yang PT, Liu XH, Dai ZJ. Lack of Association Between Polymorphisms in AGT and ATR1 and IgA Nephropathy in a Chinese Population. Genet Test Mol Biomarkers. 2015; 19:710-13. https://doi.org/10.1089/gtmb.2015.0167.

28. Chen WJ, Huang YL, Shiue HS, Chen TW, Lin YF, Huang CY, Lin YC, Han BC, Hsueh YM. Renin-angiotensinaldosterone system related gene polymorphisms and urinary total arsenic is related to chronic kidney disease. Toxicol Appl Pharmacol. 2014; 279:95-102. https://doi. org/10.1016/j.taap.2014.05.011.

29. Shah VN, Cheema BS, Sharma R, Khullar M, Kohli HS, Ahluwalia TS, Mohan V, Bhansali A. ACAC $\beta$ gene (rs2268388) and AGTR1 gene (rs5186) polymorphism and the risk of nephropathy in Asian Indian patients with type 2 diabetes. Mol Cell Biochem. 2013; 372:191-98. https://doi. org/10.1007/s11010-012-1460-2.

30. Zsom M, Fülöp T, Zsom L, Baráth A, Maróti Z, Endreffy E. Genetic polymorphisms and the risk of progressive renal failure in elderly Hungarian patients. Hemodial Int. 2011; 15:501-08. https://doi. org/10.1111/j.1542-4758.2011.00593.x.

31. Möllsten A, Vionnet N, Forsblom C, Parkkonen M, Tarnow L, Hadjadj S, Marre M, Parving HH, Groop PH. A polymorphism in the angiotensin II type 1 receptor gene has different effects on the risk of diabetic nephropathy in men and women. Mol Genet Metab. 2011; 103:66-70. https:// doi.org/10.1016/j.ymgme.2011.01.004.

32. Huang HD, Lin FJ, Li XJ, Wang LR, Jiang GR. Genetic polymorphisms of the renin-angiotensin-aldosterone system in Chinese patients with end-stage renal disease secondary to IgA nephropathy. Chin Med J (Engl). 2010; 123:3238-42.

33. Kim SM, Chin HJ, Oh YK, Kim YS, Kim S, Lim CS. Blood pressure-related genes and the progression of IgA nephropathy. Nephron Clin Pract. 2009; 113:c301-08. https://doi.org/10.1159/000235948.

34. Prasad P, Tiwari AK, Kumar KM, Ammini AC, Gupta A, Gupta R, Sharma AK, Rao AR, Nagendra R, Chandra TS, Tiwari SC, Rastogi P, Gupta BL, Thelma BK. Chronic renal insufficiency among Asian Indians with type 2 diabetes: I. 
Role of RAAS gene polymorphisms. BMC Med Genet. 2006; 7:42. https://doi.org/10.1186/1471-2350-7-42.

35. Buraczynska M, Ksiazek P, Drop A, Zaluska W, Spasiewicz D, Ksiazek A. Genetic polymorphisms of the reninangiotensin system in end-stage renal disease. Nephrol Dial Transplant. 2006; 21:979-83. https://doi.org/10.1093/ ndt/gfk012.

36. Fabris B, Bortoletto M, Candido R, Barbone F, Cattin MR, Calci M, Scanferla F, Tizzoni L, Giacca M, Carretta R. Genetic polymorphisms of the renin-angiotensinaldosterone system and renal insufficiency in essential hypertension. J Hypertens. 2005; 23:309-16. https://doi. org/10.1097/00004872-200502000-00013.

37. Woo KT, Lau YK, Choong LH, Zhao Y, Tan HB, FookChong S, Tan EK, Yap HK, Wong KS. Polymorphism of renin-angiotensin system genes in IgA nephropathy. Nephrology (Carlton). 2004; 9:304-09. https://doi. org/10.1111/j.1440-1797.2004.00291.x.

38. Stratta P, Bermond F, Guarrera S, Canavese C, Carturan S, Dall'Omo A, Ciccone G, Bertola L, Mazzola G, Fasano E, Matullo G. Interaction between gene polymorphisms of nitric oxide synthase and renin-angiotensin system in the progression of membranous glomerulonephritis. Nephrol Dial Transplant. 2004; 19:587-95. https://doi.org/10.1093/ ndt/gfg604.

39. Losito A, Kalidas K, Santoni S, Ceccarelli L, Jeffery S. Polymorphism of renin-angiotensin system genes in dialysis patients - association with cerebrovascular disease. Nephrol Dial Transplant. 2002; 17:2184-88. https://doi.org/10.1093/ ndt/17.12.2184.

40. Fradin S, Goulet-Salmon B, Chantepie M, Grandhomme F, Morello R, Jauzac P, Reznik Y. Relationship between polymorphisms in the renin-angiotensin system and nephropathy in type 2 diabetic patients. Diabetes Metab. 2002; 28:27-32.

41. Basset EA, Berthoux P, Cécillon S, Deprle C, Thibaudin D, De Filippis JP, Alamartin E, Berthou F. Hypertension after renal transplantation and polymorphism of genes involved in essential hypertension: ACE, AGT, AT1 R and ecNOS. Clin Nephrol. 2002; 57:192-200. https://doi.org/10.5414/ CNP57192.

42. Thomas GN, Critchley JA, Tomlinson B, Lee ZS, Young RP, Cockran CS, Chan JC. Albuminuria and the reninangiotensin system gene polymorphisms in type-2-diabetic and in normoglycemic hypertensive Chinese. Clin Nephrol. 2001; 55:7-15.

43. Wu S, Xiang K, Zheng T, Sun D, Weng Q, Zhao H, Li J. Relationship between the renin-angiotensin system genes and diabetic nephropathy in the Chinese. Chin Med J (Engl). 2000; 113:437-41.

44. van Ittersum FJ, de Man AM, Thijssen S, de Knijff P, Slagboom E, Smulders Y, Tarnow L, Donker AJ, Bilo HJ, Stehouwer CD. Genetic polymorphisms of the reninangiotensin system and complications of insulin-dependent diabetes mellitus. Nephrol Dial Transplant. 2000; 15:100007. https://doi.org/10.1093/ndt/15.7.1000.

45. Pei Y, Scholey J, Thai K, Suzuki M, Cattran D. Association of angiotensinogen gene T235 variant with progression of immunoglobin A nephropathy in Caucasian patients. J Clin Invest. 1997; 100:814-20. https://doi.org/10.1172/ JCI119596.

46. Marre M, Jeunemaitre X, Gallois Y, Rodier M, Chatellier G, Sert C, Dusselier L, Kahal Z, Chaillous L, Halimi S, Muller A, Sackmann H, Bauduceau B, et al. Contribution of genetic polymorphism in the renin-angiotensin system to the development of renal complications in insulindependent diabetes: genetique de la Nephropathie Diabetique (GENEDIAB) study group. J Clin Invest. 1997; 99:1585-95. https://doi.org/10.1172/JCI119321.

47. Chowdhury TA, Dyer PH, Kumar S, Gough SC, Gibson SP, Rowe BR, Smith PR, Dronsfield MJ, Marshall SM, Mackin P, Dean JD, Morris PJ, Davies S, et al. Lack of association of angiotensin II type 1 receptor gene polymorphism with diabetic nephropathy in insulin-dependent diabetes mellitus. Diabet Med. 1997; 14:837-40. https://doi. org/10.1002/(SICI)1096-9136(199710)14:10<837::AIDDIA463>3.0.CO;2-V.

48. Auton A, Brooks LD, Durbin RM, Garrison EP, Kang HM, Korbel JO, Marchini JL, McCarthy S, McVean GA, Abecasis GR, and 1000 Genomes Project Consortium. A global reference for human genetic variation. Nature. 2015; 526:68-74. https://doi.org/10.1038/nature15393.

49. Egger M, Davey Smith G, Schneider M, Minder C. Bias in meta-analysis detected by a simple, graphical test. BMJ. 1997; 315:629-34. https://doi.org/10.1136/ bmj.315.7109.629.

50. Su SL, Yang HY, Wu CC, Lee HS, Lin YF, Hsu CA, Lai CH, Lin C, Kao SY, Lu KC. Gene-gene interactions in renin-angiotensin-aldosterone system contributes to end-stage renal disease susceptibility in a Han Chinese population. Sci World J. 2014; 2014:169798. https://doi. org/10.1155/2014/169798.

51. Lin C, Yang HY, Wu CC, Lee HS, Lin YF, Lu KC, Chu CM, Lin FH, Kao SY, Su SL. Angiotensin-converting enzyme insertion/deletion polymorphism contributes high risk for chronic kidney disease in Asian male with hypertension-a meta-regression analysis of 98 observational studies. PLoS One. 2014; 9:e87604. https://doi.org/10.1371/journal. pone. 0087604 .

52. Evangelou E, Ioannidis JP. Meta-analysis methods for genome-wide association studies and beyond. Nat Rev Genet. 2013; 14:379-89. https://doi.org/10.1038/nrg3472.

53. Lin $\mathrm{C}, \mathrm{Chu} \mathrm{CM}, \mathrm{Su}$ SL. Epistasis Test in Meta-Analysis: A Multi-Parameter Markov Chain Monte Carlo Model for Consistency of Evidence. PLoS One. 2016; 11:e0152891. https://doi.org/10.1371/journal.pone.0152891.

54. Wacholder S, Chanock S, Garcia-Closas M, El Ghormli L, Rothman N. Assessing the probability that a positive report 
is false: an approach for molecular epidemiology studies. $\mathrm{J}$ Natl Cancer Inst. 2004; 96:434-42. https://doi.org/10.1093/ jnci/djh075.

55. Tan SC, Yiap BC. DNA, RNA, and protein extraction: the past and the present. J Biomed Biotechnol. 2009; 2009:574398. https://doi.org/10.1155/2009/574398.

56. Moher D, Liberati A, Tetzlaff J, Altman DG, and PRISMA Group. Preferred reporting items for systematic reviews and meta-analyses: the PRISMA statement. PLoS Med. 2009; 6:e1000097. https://doi.org/10.1371/journal.pmed.1000097.
57. Higgins JPT, Green S (editors). "Cochrane Handbook for Systematic Reviews of Interventions" Version 5.1.0 [updated March 2011]. The Cochrane Collaboration, 2011. Available from http://handbook.cochrane.org.

58. Lin C, Chu CM, Lin J, Yang HY, Su SL. Gene-gene and gene-environment interactions in meta-analysis of genetic association studies. PLoS One. 2015; 10:e0124967. https:// doi.org/10.1371/journal.pone.0124967. 